\title{
Article \\ Photobacterium halophilum sp. nov. and a Salt-Loving Bacterium Isolated from Marine Sediment
}

\author{
Minji Kim ${ }^{1}$, Ki-Eun Lee ${ }^{2}$, In-Tae Cha ${ }^{2, *}$ and Soo-Je Park ${ }^{1, *(D)}$ \\ 1 Department of Biology, Jeju National University, Jeju 63243, Korea; mminji.k96@gmail.com \\ 2 Microorganism Resources Division, National Institute of Biological Resources, Incheon 22689, Korea; \\ leege7@korea.kr \\ * Correspondence: itcha@korea.kr (I.-T.C.); sjpark@jejunu.ac.kr (S.-J.P.); \\ Tel.: +82-32-590-7175 (I.-T.C.); +82-64-754-3524 (S.-J.P.); Fax: +82-32-590-7230 (I.-T.C.); +82-64-756-3541 (S.-J.P.)
}

check for updates

Citation: Kim, M.; Lee, K.-E.; Cha, I.-T.; Park, S.-J. Photobacterium halophilum sp. nov. and a Salt-Loving Bacterium Isolated from Marine Sediment. Diversity 2022, 14, 188. https://doi.org/10.3390/d14030188

Academic Editor: Ipek Kurtboke

Received: 7 February 2022

Accepted: 3 March 2022

Published: 4 March 2022

Publisher's Note: MDPI stays neutral with regard to jurisdictional claims in published maps and institutional affiliations.

Copyright: (C) 2022 by the authors. Licensee MDPI, Basel, Switzerland. This article is an open access article distributed under the terms and conditions of the Creative Commons Attribution (CC BY) license (https:// creativecommons.org/licenses/by/ $4.0 /)$.

\begin{abstract}
A Gram-stain-negative, rod-shaped, and facultatively anaerobic bacterium named strain $\mathrm{GJ} 3^{\mathrm{T}}$ was isolated from coastal sediment of Jeju Island, South Korea. Catalase and oxidase activity were detected in the cell of strain $\mathrm{GJ}^{\mathrm{T}}$, as well as white pigmented colony and motility with polar flagellum. The cell grew optimally at $30{ }^{\circ} \mathrm{C}, \mathrm{pH} 7.0$, in the presence of $4 \%(w / v)$ sodium chloride. Phylogenetic analysis using the $16 \mathrm{~S}$ rRNA gene sequence indicated that strain $\mathrm{GJ} 3^{\mathrm{T}}$ was classified to the genus Photobacterium, with high sequence similarity to Photobacterium galatheae S2753 ${ }^{\mathrm{T}}$ (98.30\%), Photobacterium halotolerans MACL01 ${ }^{\mathrm{T}}$ (97.90\%), and Photobacterium panuliri $\mathrm{LBS5}^{\mathrm{T}}(96.55 \%)$. Strain $\mathrm{GJ} 3^{\mathrm{T}}$ possessed only ubiquinone- $8(\mathrm{Q}-8)$ as a respiratory quinone and summed feature 8 as the major fatty acid (38.18\%). Additionally, the dominant polar lipids phosphatidylglycerol and phosphatidylethanolamine were identified. The complete genome size and $\mathrm{G}+\mathrm{C}$ content of strain $\mathrm{GJ} 3^{\mathrm{T}}$ was estimated to be 3,603,274 bp in length and 50.70\%, respectively. Polyphasic approach and genomic analyses (e.g., ANI and digital DDH) revealed that strain GJ3 ${ }^{\mathrm{T}}\left(=\mathrm{KCTC} 72816^{\mathrm{T}}=\mathrm{KMM}\right.$ $6822^{\mathrm{T}}$ ) represented a novel species within the genus Photobacterium, and the name Photobacterium halophilum sp. nov., is proposed for this novel bacterium.
\end{abstract}

Keywords: Photobacterium halophilum; tidal flat; sediment; genome; polyphasic; novel species

\section{Introduction}

The taxonomy study is a definition for nomenclature and classification for (microbial) organisms in nature ecosystem based on their shared properties, including 16S rRNA gene sequence [1,2]. To classify the organisms, the phenotypical properties were considered as a key distinguishing feature; however, it was dramatically included with genotypic characterizations (e.g., DNA-DNA relatedness) [3,4]. Then, the bacterial systematics (i.e., taxonomy study) is supposed as a consensually polyphasic approach [1]. Nonetheless, this polyphasic approach has a critical limitation that this research can apply to the already isolated (i.e., cultivated) microorganisms in the laboratory [5] or technical handling concerns (e.g., DNA-DNA hybridization) [6].

In the sequencing era, the taxonomic assignment for bacterial organisms has been challenged, resulting in reclassification of the incorrectly identified taxa and revisiting their ecological implications [7-11]. At the moment, as a genomic gold standard, genomes are dramatically applied into the definition for prokaryotic species. The average nucleotide identity (ANI) and digital DNA-DNA hybridization (dDDH) have been most frequently utilized in these sorts of studies [12-14]. Additionally, the value for the average amino acid identity (AAI) is employed for novel species validation [15].

During a culturable-bacterial diversity investigation of marine environments, including coastal sediments on Jeju Island, South Korea, we isolated a novel bacterium belonging to the genus Photobacterium, designated as GJ3 ${ }^{\mathrm{T}}$. The genus Photobacterium belongs to the family Vibrionaceae and the phylum Proteobacteria. It was first proposed by 
Beijerink et al. [16] with the description of Photobacterium phosphoreum as the type species. At the time of this writing, the genus Photobacterium has 42 species with valid names (https://lpsn.dsmz.de/genus/photobacterium, accessed on 10 January 2022). The species of the genus Photobacterium have been mostly isolated from marine and aquatic environments, including samples associated with marine animals [17-25]. Members of this genus share common characteristics of being Gram-stain negative, facultative anaerobic, motile, and rod shaped with cells containing ubiquinone $8(\mathrm{Q}-8)$ as a major or sole respiratory quinone [16]. Additionally, some Photobacterium species are luminous due to the presence of the lux gene (luxCDABEG), and many marine fish species form bioluminescent through these Photobacterium species [26]. Therefore, in this study, we describe its taxonomic properties, including biochemical and genomics traits. Finally, we proposed the strain GJ3 ${ }^{\mathrm{T}}$ as a representative novel species of the genus Photobacterium.

\section{Materials and Methods}

\subsection{Isolation and Culture Conditions}

Strain GJ3 ${ }^{\mathrm{T}}$ was isolated from a coastal sediment sample on Jeju Island (March 2019), South Korea (GPS; $33^{\circ} 27^{\prime} 15 \mathrm{~N}, 126^{\circ} 18^{\prime} 26 \mathrm{E}$ ). The sample was collected into a falcon tube, stored in a container maintained at $4{ }^{\circ} \mathrm{C}$ by icepack, and transported to the laboratory. To isolate bacteria, a sediment sample was placed in a sterile $50-\mathrm{mL}$ conical tube and slurried with artificial seawater (ASW) [27]. After serial dilution to $10^{-5}$, the diluted slurry was spread onto marine agar 2216 (MA; BD Difco) plates. For two weeks, these plates were incubated at $30{ }^{\circ} \mathrm{C}$. Single colonies were transferred to new MA plates. Each colony was subcultured on MA plates at least five times to obtain a pure colony. Cells were subcultured and grown on $\mathrm{MA}$ at $30^{\circ} \mathrm{C}$ for 3 days before being stored at $-80^{\circ} \mathrm{C}$ as a suspension in marine broth (MB; BD Difco) supplemented with $30 \%(w / v)$ glycerol for subsequent analyses. Based on $16 \mathrm{~S}$ rRNA gene sequence similarity and phylogenetic position, Photobacterium galatheae $\mathrm{S} 2753^{\mathrm{T}}$ $\left(\mathrm{LMG} 28894^{\mathrm{T}}\right)$ and Photobacterium halotolerans MACL01 ${ }^{\mathrm{T}}\left(\mathrm{LMG} 22194^{\mathrm{T}}\right)$ were selected and obtained from Belgian Coordinated Collections of Microorganisms (BCCM/LMG) as experimental reference strains for comparison with strain $\mathrm{GJ} 3^{\mathrm{T}}$. Strain $\mathrm{GJ} 3^{\mathrm{T}}$ was deposited in the Korean Collection for Type Cultures (KCTC) and Collection of Marine Microorganisms $(\mathrm{KMM})$ as KCTC $72816^{\mathrm{T}}$ and $\mathrm{KMM} 6822^{\mathrm{T}}$, respectively. Unless otherwise stated, all strains were grown on MA medium under their optimal culture conditions. However, during paper writing after polyphasic experiments, Photobacterium salinisoil LAM $9072^{\mathrm{T}}$ has been validly published by Li et al. [28]. We conducted whole-genome-based taxonomic analyses (such as digital DNA-DNA hybridization (dDDH), average nucleotide identity (ANI), and average amino acid identity (AAI)) for genomes of $P$. salinisoli and the isolated strain GJ3 $3^{\mathrm{T}}$ (see DDH results and discussion on genomics relatedness).

\subsection{Phylogenetic Analysis}

To determine the phylogenetic position of strain $\mathrm{GJ} 3^{\mathrm{T}}$, genomic DNA (gDNA) was extracted using a commercial gDNA extraction kit (GeneAll Biotechnology Co., Ltd., Seoul, Korea) according to the manufacturer's instructions. The $16 \mathrm{~S}$ rRNA gene was amplified by polymerase chain reaction (PCR) using gDNA as template and universal bacterial primer set 27F (5'-AGAGTTTGATCMTGGCTCAG-3') and 1492R (5'-TACGGYTACCTTGTTACGACTT-3') as previously described [29]. For sequencing the amplified 16S rRNA gene, the PCR product was purified using a PCR purification kit (GeneAll Biotechnology Co., Ltd.) according to the manufacturer's instructions. Sequencing of the $16 \mathrm{~S}$ rRNA gene was performed using primers $27 \mathrm{~F}, 518 \mathrm{~F}, 800 \mathrm{R}$, and $1492 \mathrm{R}$ as described previously [29,30]. Finally, the $16 \mathrm{~S}$ rRNA gene sequence of strain $\mathrm{GJ}^{\mathrm{T}}$ (1474bp) was obtained using SeqMan software (DNASTAR) and compared with sequences of related taxa obtained from the GenBank database (www.ncbi.nlm.nih.gov, accessed on 12 January 2022) and the EzBioCloud server (https: / / www.ezbiocloud.net, accessed on 12 January 2022). Sequences were edited and aligned using Clustal_X of BioEdit program [31]. Evolutionary distances were calculated using the Kimura two-parameter model [32]. The neighbor-joining [33], maximum parsi- 
mony [34], and maximum likelihood methods [35] were used to reconstruct phylogenetic trees in MEGA X software [36], with bootstrap values based on 1000 replications.

\subsection{Phenotypic and Biochemical Characteristics}

Unless otherwise specified, strain $\mathrm{GJ} 3^{\mathrm{T}}$ and selected reference strains (P. galatheae LMG $28894^{\mathrm{T}}$ and P. halotolerans LMG $22194^{\mathrm{T}}$ ) were cultivated on MA at $30^{\circ} \mathrm{C}$ until the mid-exponential phase to obtain the best results for physiological and biochemical characterization. Cell morphology and size were examined by transmission electron microscopy (JEOLJEM-1010, JEOL Ltd., Tokyo, Japan) using negative staining with $1 \%(w / v)$ phosphotungstic acid. Cell motility was tested with the hanging-drop method [37]. The temperature range and optimum temperature for growth were determined by incubation on MA at 4, 10, $15,18,25,30,37,42$, and $45^{\circ} \mathrm{C}$. The $\mathrm{pH}$ range and optimal $\mathrm{pH}$ for growth were determined on $\mathrm{MB}$ to $\mathrm{pH} 4.0-10.0$ at increments of $0.5 \mathrm{pH}$ units adjusted by the following buffering system: homopiperazine-1,4-bis-2-ethanesulfonic acid ( $\mathrm{pH}$ 4.0-5.0), 2-( $\mathrm{N}$-morpholino) ethanesulfonic acid ( $\mathrm{pH}$ 5.5-6.5), 1,3-bis[tris(hydroxymethyl)methylamino]propane ( $\mathrm{pH} 7.0-8.5$ ), and 3-(cyclohexylamino)-1-propanesulfonic acid (pH 9.0-10.0). To estimate salinity tolerance, the novel strain was grown in artificial seawater (ASW) [27] medium containing 0 to $10 \%(w / v) \mathrm{NaCl}$ (at intervals of $1 \%)$ supplemented with peptone $(1 \%, w / v)$ and yeast extract $(0.5 \%, w / v)$. Gram staining was performed using a BD Gram-staining kit. Anaerobic growth was examined over two weeks on MA plates using a BD GasPak ${ }^{\mathrm{TM}} \mathrm{EZ}$ Anaerobe pouch system (BD Diagnostics). Catalase activity was determined based on the production of oxygen bubbles after mixing cells with $3 \%(v / v) \mathrm{H}_{2} \mathrm{O}_{2}$. An oxidase test was performed using $1 \%(w / v)$ tetramethyl-p-phenylenediamine (Merck). The hydrolysis of skim milk $(0.2 \%, w / v)$, CM-cellulose $(0.2 \%, w / v)$, starch $(0.2 \%, w / v)$, and tween $60(1.0 \%, w / v)$ was determined based on the formation of clear zones around colonies after applying suitable solutions based on the method described by Smibert and Krieg [38]. DNA degradation was tested using DNase test agar (BD Difco) containing up to $3.0 \% \mathrm{NaCl}$. Biochemical tests were carried out using API 20NE, API 32GN, and API ZYM test strips (bioMérieux) with bacterial suspensions in ASW medium. For antimicrobial susceptibility test, strain GJ3 ${ }^{\mathrm{T}}$ was grown on MA in the presence of disks containing various antimicrobial compounds (penicillin G, $10 \mathrm{IU}$; tetracycline, $30 \mu \mathrm{g}$; gentamicin, $10 \mu \mathrm{g}$; oxacillin, $1 \mu \mathrm{g}$; clindamycin, $2 \mu \mathrm{g}$; kanamycin, $30 \mu \mathrm{g}$; streptomycin, $10 \mu \mathrm{g}$; ampicillin, $10 \mu \mathrm{g}$; sulfamethoxazole/trimethoprim, 23.75/1.25 $\mu \mathrm{g}$; neomycin, $30 \mu \mathrm{g}$ ) for two weeks at $30^{\circ} \mathrm{C}$.

\subsection{Chemotaxonomic Analyses}

Whole-cell fatty acid methyl ester compositions of GJ3 $3^{\mathrm{T}}$ and two reference strains were determined using a $6890 \mathrm{~N}$ gas chromatograph (Agilent Technologies, Santa Clara, CA, USA). Cultivation of strains, harvesting of cells, fatty acid extraction, and analysis of fatty acid methyl esters were performed according to recommendations of the Sherlock Microbial Identification System (MIDI). For fatty acid analysis, all strains were grown on MA for 3 days at $30^{\circ} \mathrm{C}$ under aerobic conditions. They were then identified using the TSBA identification library version 5.0. For quinone and polar lipid analyses, GJ3 $3^{\mathrm{T}}, P$. galatheae LMG $28894^{\mathrm{T}}$, and P. halotolerans LMG $22194^{\mathrm{T}}$ cultures first underwent lyophilization. Quinones were extracted as described by $\mathrm{Hu}$ et al. [39]. Quinone component was separated and identified by reversed-phase high-performance liquid chromatography as previously described [30]. Polar lipids were extracted according to procedures described by Minnikin et al. [40] and separated by two-dimensional thin-layer chromatography as described by Minnikin et al. [41].

\subsection{Whole-genome Sequencing and Genome Analyses}

For whole-genome sequencing, 20-kb SMRTbell ${ }^{\mathrm{TM}}$ template libraries were constructed using the extracted gDNA. Whole-genome sequencing of $\mathrm{GJ} 3^{\mathrm{T}}$ was performed using a PacBio RSII platform (Pacific Biosciences, Menlo Park, CA, USA) at DNA Link, Inc. (Seoul, Korea). Sequences were obtained from high-quality reads with about 244-fold coverage 
and assembled using a hierarchical genome assembly process (HGAP, v3.0) with assembly polishing using Quiver [42]. To examine species boundaries, ANI [43] values, AAI [44], and dDDH were calculated using an ANI calculator (http:/ / enve-omics.ce.gatech.edu/ani/, accessed on 13 January 2022), AAI (http:/ / enveomics.ce.gatech.edu/aai/, accessed on 13 January 2022), and a genome-to-genome comparison (GGDC) [45], respectively. Before genomic trait analysis, the genome of $\mathrm{GJ}^{\mathrm{T}}$ was annotated using the Prokaryotic Genome Annotation Pipeline (PGAP) [46]. There was no difference between the 16S rRNA gene sequence identified from the whole-genome sequence and that obtained by the PCR-Sanger sequencing method (see phylogenetic analysis).

The genome sequence data were uploaded to the Type (Strain) Genome Server (TYGS), a public bioinformatics platform available at https:/ / tygs.dsmz.de (accessed on 13 January 2022) for whole genome-based taxonomic analysis [47]. Information on nomenclature, synonymy, and associated taxonomic literature was obtained from TYGS's sister database, the List of Prokaryotic names with Standing in Nomenclature (LPSN, available at https:/ /lpsn.dsmz.de, accessed on 13 January 2022) [48]. For phylogenomic inference, all pairwise comparisons among the set of genomes were conducted using GBDP and accurate intergenomic distances inferred under the algorithm "trimming" and distance formula d5 [45]. One hundred distance replicates each were calculated. Digital DDH values and confidence intervals were calculated using recommended settings of the GGDC 3.0 [45,48]. Resulting intergenomic distances were used to infer a balanced minimum evolution tree with branch support via FASTME 2.1.6.1, including SPR postprocessing [49]. Branch support was inferred from 100 pseudo-bootstrap replicates each. Trees were rooted at the midpoint [50] and visualized with PhyD3 [51].

Prophage, clustered regularly interspaced short palindromic repeats (CRISPRs), and secondary metabolite clusters were identified and annotated by the online tools phage search tool enhanced release (PHASTER), CRISPRFinder, and antiSMASH bacterial version (v. 6.0), respectively [52-54].

\section{Results and Discussion}

\subsection{Phylogenetic, Phylogenomic, and Genome Features}

The 16S rRNA gene sequence revealed that strain $\mathrm{GJ}^{\mathrm{T}}$ was clearly clustered to the genus Photobacterium (Figure 1). Based on the sequence similarity in EzBioCloud server, $\mathrm{GJ}^{\mathrm{T}}$ was most closely related to Photobacterium galatheae $\mathrm{S} 2753^{\mathrm{T}}(98.30 \% 16 \mathrm{~S}$ rRNA gene sequence similarity), followed by Photobacterium halotolerans $\mathrm{MACL0}^{\mathrm{T}}(97.90 \%)$, and Photobacterium panuliri $\mathrm{LBS}^{\mathrm{T}}(96.55 \%)$. The sequence similarity between $\mathrm{GJ}^{\mathrm{T}}$ and the additional-validated strain P. salinisoil LAM $9072^{\mathrm{T}}$ was $98.55 \%$. Additionally, the resultant phylogenomics tree provided strong evidence that strain $\mathrm{GJ}^{\mathrm{T}}$ belonged to the genus Photobacterium (Figure 2).

From genome, the branch lengths are scaled in terms of GBDP distance formula d5. Numbers above branches are GBDP pseudo-bootstrap support values $>60$ assemble, a complete circular genome 3,603,274 bp length with a G+C content of $50.70 \%$ and two plasmids. The values for ANI, AAI, and $\mathrm{dDDH}$ between $\mathrm{GJ}^{\mathrm{T}}$ and two selected reference strains were calculated by $79.24 \%, 81.94 \%$, and $23.50 \%$ (P. galatheae LMG $28894^{\mathrm{T}}$ ), and $77.90 \%, 81.83 \%$, and $22.30 \%$ (P. halotolerans LMG $22194^{\mathrm{T}}$ ), respectively. In addition, those values between GJ3 ${ }^{\mathrm{T}}$ and $P$. salinisoli LAM 9072 ${ }^{\mathrm{T}}$ (GenBank access. No. GCA_003614885) were $81.11 \%, 81.99 \%$, and $22.30 \%$, respectively. Despite its $16 \mathrm{~S}$ rRNA gene sequence similarity with P. salinisoli (98.55\%) was slightly higher than P. galatheae $(98.30 \%)$, values of ANI, AAI, and dDDH from whole-genome-based genomic analyses indicated that $\mathrm{GJ}^{\mathrm{T}}$ was clearly distinguished from $P$. salinisoli as a novel species. Strain GJ3 ${ }^{\mathrm{T}}$ clearly represented a novel species in the genus Photobacterium based on ANI and dDDH criterion values $[43,47]$. 


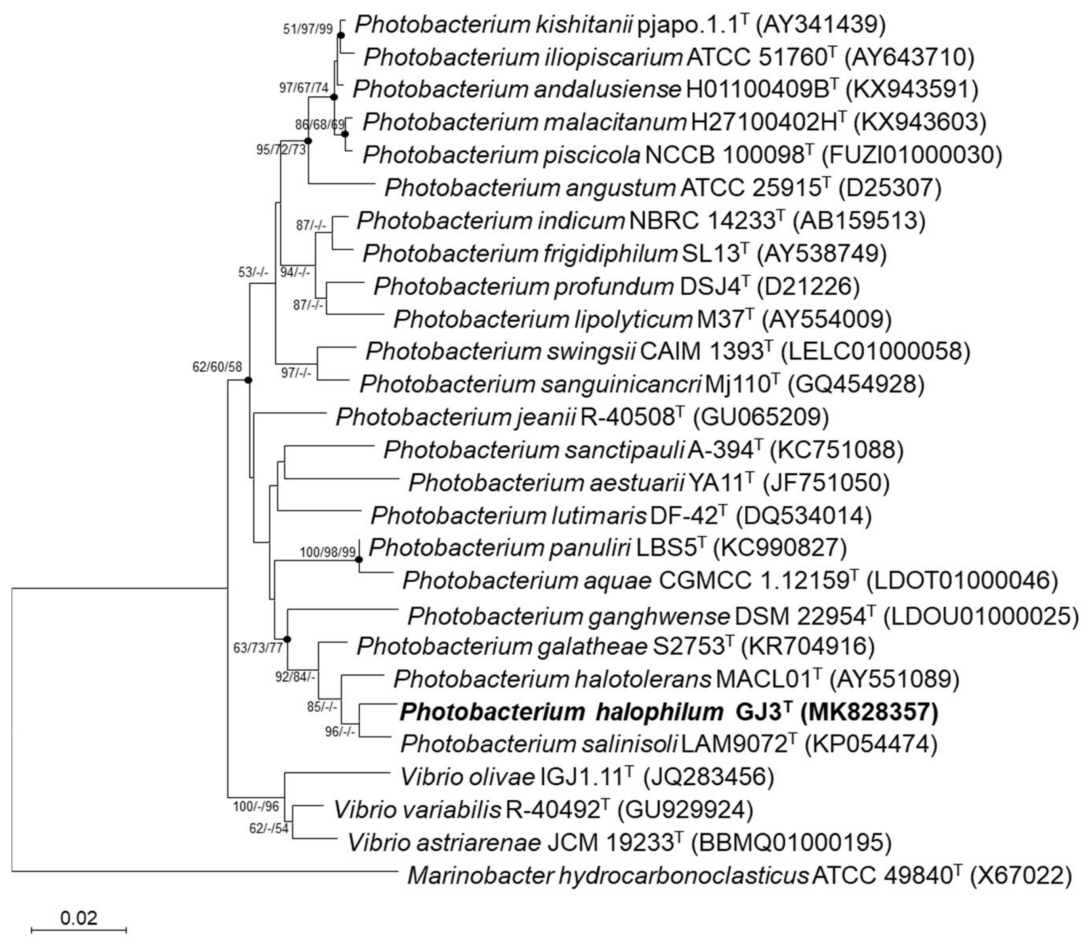

Figure 1. Neighbor-joining tree based on 16S rRNA gene sequences showing the phylogenetic relationship of strain $\mathrm{GJ} 3^{\mathrm{T}}$ and related strains, including validated members of the genus Photobacterium. The sequence of Marinobacter hydrocarbonoclasticus ATCC $49840^{\mathrm{T}}($ X67022) was used as an outgroup in this study. GenBank accession numbers are given in parentheses. Bootstrap values $(>50 \%)$ based on 1000 replications are shown at nodes based on neighbor-joining, maximum likelihood, and maximum parsimony methods. Filled circles indicated that the corresponding nodes were also obtained in the trees generated with the neighbor-joining, maximum likelihood, and maximum parsimony methods. Bars, 0.02 substitutions per nucleotide position.

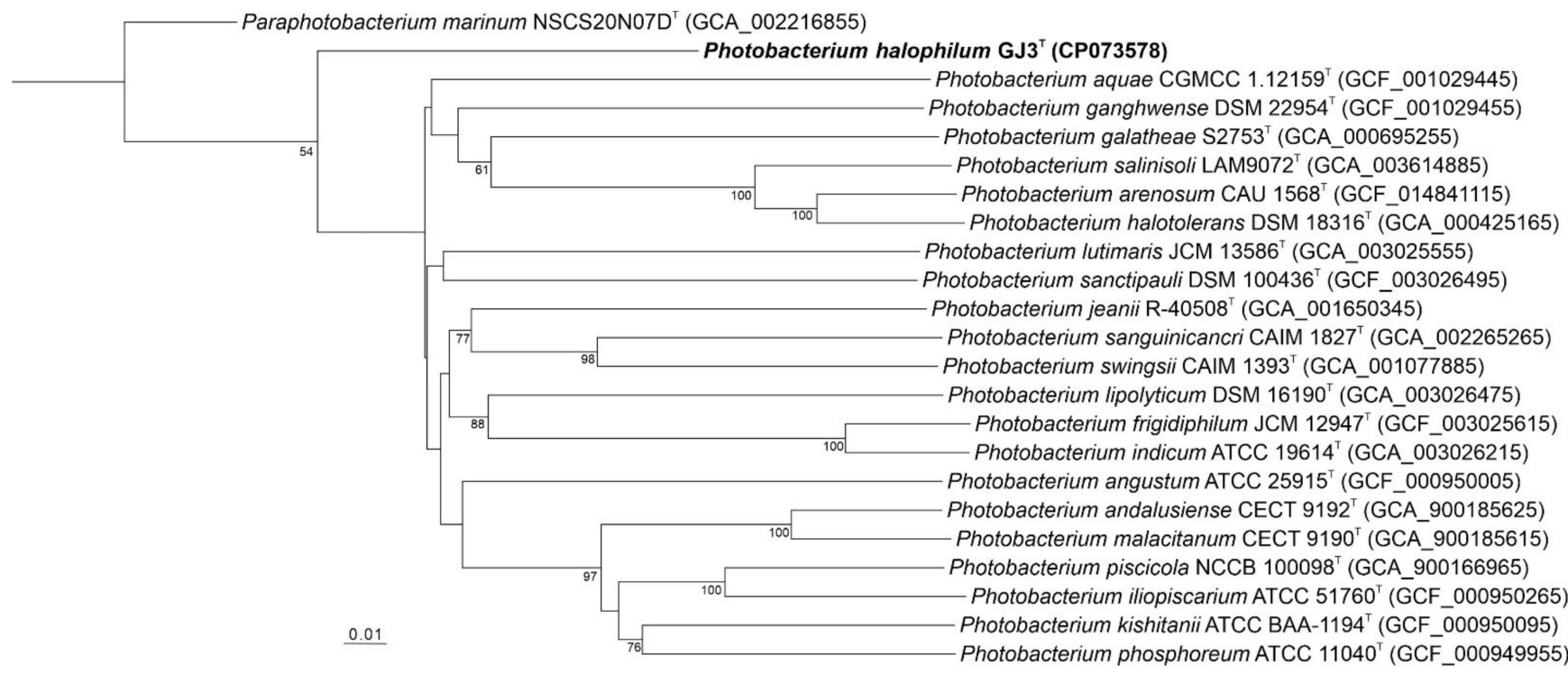

Figure 2. Whole-genome sequence-based tree inferred with FastME 2.1.6.1 [49] from GBDP distances calculated from strain $\mathrm{GJ}^{\mathrm{T}}$ and relative genome sequences. The branch lengths are scaled in terms of GBDP distance formula $d_{5}$. Numbers above branches are GBDP pseudo-bootstrap support values $>60 \%$ from 100 replications, with average branch support of $55.6 \%$. The tree was rooted at the midpoint [51]. 
Strain GJ3 ${ }^{\mathrm{T}}$ genome was annotated by PGAP predicted 4719 coding sequences (CDSs) and 164 RNAs, including 125 transfer RNAs and 6 non-coding RNA genes. A total of 2259 CDSs were matched in the Kyoto Encyclopedia of Genes and Genomes (KEGG) database $(47.87 \%$ of total CDSs). Based on KEGG results, quinone electron carrier (ArcBA) enzymes for anaerobic respiration and low nitrogen availability (GlnDBLGA) were found in the genome. Anaerobic respiration enzymes (FrdABCD) for converting fumarate to succinate and regulating the expression of anaerobic respiration gene (NarQL) and dissimilatory nitrate reduction (NapAB and NirBD) were also found in the genome, indicating that strain $\mathrm{GJ} 3^{\mathrm{T}}$ can grow under a low oxygen environment $[55,56]$.

Strain GJ3 ${ }^{\mathrm{T}}$ genome encoded enzymes for phosphate limitation (PhoRB), misfolded proteins (CpxAR, HtrA), and $\mathrm{Mg}^{2+}$ starvation and antimicrobial peptide (PhoQP). In addition, the genome contained gene contents entirely for bacterial chemotaxis, including flagella assembly (cheWYARYVB). The genome of strain GJ3 $3^{\mathrm{T}}$ included entire genes for the biosynthesis of ectoine and glycine betaine as a compatible solute. These have been implicated in the maintenance of osmotic equilibrium in hypersaline environments [57]. The resultant comparative genomic analysis for the genus Photobacterium showed that biosynthetic gene cluster for ectoine has been well presented in a number of species of the genus [58]. These results indicate that strain $\mathrm{GJ}^{\mathrm{T}}$ might have an ecological advantage for surviving in various environments, including nutrient starvation. Additionally, using antiSMASH analysis, the genome encoded the genes for the biosynthesis for non-ribosomal peptide synthetase cluster, althiomycin, and type I PKS (polyketide synthase) with antagonistic properties, including antibiotics [59]. Unexpectedly, the gene cluster for butyrolactone synthesis has firstly been identified in the Photobacterium spp. genomes. The butyrolactone is related to a quorum sensing molecule, regulating for antibiotic production and cell differentiation in streptomyces [60]. Taken together, although natural secondary-metabolic compounds are commonly produced from various organisms, including plant, this result indicates that strain $\mathrm{GJ} 3^{\mathrm{T}}$ may have a competitive benefit against other organisms [61].

Interestingly, the gene encoding the biosynthesis of siderophores aerobactin (iuc) was found in the genome of strain $\mathrm{GJ}^{\mathrm{T}}{ }^{\mathrm{T}}$. This gene has been widely reported in members of pathogenic genera, including Vibrio [62]. The gene involved in siderophores synthesis is known as related to virulence (e.g., Klebseilla [63]). However, for non-pathogenic species, the gene might have been acquired via horizontal gene transfer (HGT) [64]. It was deduced that this gene might have a strategic advantage for iron uptake from the environment. To the best of our knowledge, in the genus Photobacterium, except strain $\mathrm{GJ}^{\mathrm{T}}{ }^{\mathrm{T}}$, the iuc gene encoded in the P. halotolerans MELD1 genome was reported [65]. Also, we only identified three incomplete prophage regions (score $<70$ estimated by PHASTER) in the strain GJ3 ${ }^{\mathrm{T}}$ genome with slightly lower GC range $(47.09-47.86 \%)$ than its genome GC $(50.70 \%)$. In these prophage sequences, genes involved in transposase, integrase, hypothetical protein, exonuclease, recombination, and tail assembly were identified. However, we found no CRISPRs in the genome. Taken together, these results indicate that strain GJ3 ${ }^{\mathrm{T}}$ might have a little stress for genetic exchange of foreign DNA (i.e., HGT via phage), and there might be no driving force for evolution opportunity (e.g., genome conservation) in their habits $[66,67]$.

\subsection{Physiology and Chemotaxonomy}

The isolated strain GJ3 ${ }^{\mathrm{T}}$ was Gram-stain-negative, catalase- and oxidase-positive, facultatively anaerobic, white pigmented, motile, and rod shaped (Figure S1). Cells grew at $15-37^{\circ} \mathrm{C}$ (optimum: $30^{\circ} \mathrm{C}$ ), $\mathrm{pH} 5.5-8.5$ (optimum: 7.0), and with $0.5-9.0 \%(w / v) \mathrm{NaCl}$ (optimum: $4 \%$ ) under aerobic conditions. Cells were sensitive to ampicillin, kanamycin, tetracycline, gentamicin, neomycin, and sulfamethoxazole/trimethoprim, but resistant to penicillin, oxacillin, clindamycin, and streptomycin. Degradation activity for starch, skim milk, DNase, cellulose, and Tween 60 was not observed. In addition, strain GJ3 ${ }^{\mathrm{T}}$ was negative for reduction of nitrates to nitrite, reduction of nitrates to nitrogen, indole production, and glucose acidification. Numerous additional phenotypic characteristics, as 
listed in Table 1, can be used to differentiate strain $\mathrm{GJ} 3^{\mathrm{T}}$ from the experimental reference strains used in this study.

Table 1. Differential physiological characteristics of strain $\mathrm{GJ}^{\mathrm{T}}$ and reference strains of the genus Photobacterium.

\begin{tabular}{|c|c|c|c|c|}
\hline Characteristics & 1 & 2 & 3 & $4 *$ \\
\hline Temperature range $\left({ }^{\circ} \mathrm{C}\right)$ & $15-37$ & $15-40$ & $4-37$ & $10-40$ \\
\hline $\mathrm{NaCl}$ range $(\%, w / v)$ & $0.5-9.0$ & $0.5-9.0$ & $0-8.0$ & $0-9.0$ \\
\hline Oxidase & + & + & + & - \\
\hline Nitrate reduction $\left(\mathrm{NO}_{3}{ }^{-} \rightarrow \mathrm{NO}_{2}{ }^{-}\right)$ & - & + & + & - \\
\hline Glucose acidification & - & + & + & ND \\
\hline \multicolumn{5}{|c|}{ Utilization of (as sole carbon and energy source): } \\
\hline D-Mannose & + & - & + & - \\
\hline Gluconate & - & - & + & + \\
\hline Adipate & - & - & + & ND \\
\hline Malate & - & + & + & ND \\
\hline D-Mannitol & - & - & - & + \\
\hline L-Arabinose & + & - & + & ND \\
\hline D-Maltose & - & + & + & ND \\
\hline Citrate & - & - & - & + \\
\hline Glycogen & - & + & + & + \\
\hline \multicolumn{5}{|l|}{ Enzyme activity: } \\
\hline Protease (gelatin hydrolysis) & + & - & + & - \\
\hline Esterase (C4) & - & + & + & + \\
\hline Esterase lipase (C8) & - & + & + & + \\
\hline$\alpha$-glucosidase & - & - & - & + \\
\hline N-Acetyl-D-glucosamine & - & + & + & ND \\
\hline DNA G $+C$ content $(\%, \mathrm{~mol} / \mathrm{mol})$ & 50.7 & 49.5 & 49.8 & 50.2 \\
\hline
\end{tabular}

Strains: $1 . \mathrm{GJ}^{\mathrm{T}}$; 2. P. galatheae LMG $28894^{\mathrm{T}}$; 3. P. halotolerans LMG $22194^{\mathrm{T}}$; 4. P. salinisoli $\mathrm{LAM} 9072^{\mathrm{T}}$. All strains were Gram-stain-negative and catalase positive. All strains were positive for activities of valine arylamidase and acid phosphatase, but negative for arginine dihydrolase and $\beta$-glucosidase (esculin hydrolysis) as a sole source of carbon and energy. +, Positive; -, Negative; ND, not determined. 1, 2, 3 data from in this study; and *, data from Li et al. [28].

The major fatty acid found in strain $\mathrm{GJ}^{\mathrm{T}}$ was summed feature $8\left(\mathrm{C}_{18: 1} \omega 7 c / \mathrm{C}_{18: 1}\right.$ $\omega 6 c, 38.18 \%$ ), which is consistent with the fatty acid compositions of other type strains of the genus Photobacterium (Table 2). Individual polar lipids were identified using molybdophosphoric acid, molybdenum blue, ninhydrin, $\alpha$-naphtol reagents [40,41], and Dragendorff's reagent (Sigma). Phosphatidylethanolamine (PE), phosphatidylglycerol (PG), phosphatidylcholine (PC), and phospholipid (PL) were identified from the strain GJ3 ${ }^{\mathrm{T}}$ (Figure S2). Ubiquinone $8(\mathrm{Q}-8)$ was the sole ubiquinone expressed in the GJ3 ${ }^{\mathrm{T}}$ strain, which was consistent with the results obtained with other validated strains.

Based on morphological, physiological, and chemotaxonomic properties, as per the results of phylogenetic and genomics analysis (i.e., phylogenomics, dDDH relatedness, ANI, and AAI), GJ $3^{\mathrm{T}}$ belongs to the genus Photobacterium, and represents a novel species.

\subsection{Description of Photobacterium halophilum sp. nov.}

Photobacterium halophilum (ha.lo' phi.lum. Gr. masc. n. hals, halos salt; Gr. masc. adj. philos loving; N.L. neut. adj. halophilum salt-loving).

Gram-stain-negative, facultatively anaerobic, white pigmented, rod-shaped $(1.0 \times 2.5 \mu \mathrm{m})$, and motile with flagellum. Colonies are circular, convex, and entire, developed after incubation for 3 days at $30^{\circ} \mathrm{C}$ on MA. Cell growth occurs between 15 and $37^{\circ} \mathrm{C}$ (optimal temperature $30^{\circ} \mathrm{C}$ ), $\mathrm{pH} 5.5-8.5$ (optimal pH 7.0), and 0.5-9.0\% (w/v) NaCl (optimum of 4.0\% $(w / v) \mathrm{NaCl}$ ). Cells are catalase and oxidase positive, but are negative for reduction of nitrates to nitrite, reduction of nitrates to nitrogen, indole production, and glucose acidification. Moreover, cells cannot hydrolyze starch, skim milk, DNA, or Tween 60. 
Table 2. Cellular fatty acid profiles (\% of totals) of $\mathrm{GJ} 3^{\mathrm{T}}$ and reference strains of the genus Photobacterium.

\begin{tabular}{|c|c|c|c|}
\hline & 1 & 2 & 3 \\
\hline \multicolumn{4}{|l|}{ Saturated } \\
\hline $\mathrm{C}_{12: 0}$ & 6.37 & 6.14 & 5.17 \\
\hline $\mathrm{C}_{14: 0}$ & 0.87 & 1.06 & 1.43 \\
\hline $\mathrm{C}_{16: 0}$ & 15.75 & 17.67 & 17.05 \\
\hline $\mathrm{C}_{17: 0}$ & 0.88 & 1.47 & 1.29 \\
\hline $\mathrm{C}_{18: 0}$ & 0.60 & $\mathrm{TR}$ & $\mathrm{TR}$ \\
\hline \multicolumn{4}{|l|}{ Unsaturated } \\
\hline $\mathrm{C}_{16: 1} \omega 5 c$ & TR & TR & 0.79 \\
\hline $\mathrm{C}_{16: 1} \omega 9 c$ & 1.79 & 2.00 & 2.62 \\
\hline $\mathrm{C}_{17: 1} \omega 6 c$ & $\mathrm{TR}$ & 0.54 & 0.78 \\
\hline $\mathrm{C}_{17: 1} \omega 8 c$ & 1.77 & 2.08 & 1.96 \\
\hline $\mathrm{C}_{18: 1} \omega 9 c$ & 0.87 & $\mathrm{TR}$ & 0.56 \\
\hline \multicolumn{4}{|l|}{ Branched-chain fatty acid } \\
\hline $\mathrm{C}_{16: 0}$ iso & 0.79 & 1.53 & 2.34 \\
\hline $\mathrm{C}_{17: 0}$ iso & $\mathrm{TR}$ & $\mathrm{TR}$ & 0.68 \\
\hline \multicolumn{4}{|l|}{ Hydroxy fatty acids } \\
\hline $\mathrm{C}_{18: 0} 2 \mathrm{OH}$ & 0.81 & TR & TR \\
\hline $\mathrm{C}_{12: 0} 3 \mathrm{OH}$ & TR & 4.16 & 4.56 \\
\hline \multicolumn{4}{|l|}{ Summed feature } \\
\hline $2 ; \mathrm{C}_{12: 0}$ aldehyde & 3.89 & 3.66 & 3.88 \\
\hline $3 ; \mathrm{C}_{16: 1} \omega 6 c / \mathrm{C}_{16: 1} \omega 7 c$ & 23.71 & 28.98 & 28.36 \\
\hline $8 ; C_{18: 1} \omega 7 c / C_{18: 1} \omega 6 c$ & 38.18 & 26.29 & 23.99 \\
\hline
\end{tabular}

Strains: $1 . \mathrm{GJ}^{\mathrm{T}}$; 2. P. galatheae LMG $28894^{\mathrm{T}}$; 3. P. halotolerans LMG $22194^{\mathrm{T}}$. All strains were aerobically grown on marine agar plates at $30^{\circ} \mathrm{C}$ for 3 days. These values indicate total fatty acid percentages. TR, trace amount $(<0.5 \%)$. All data presented are those obtained from the present study.

Cells are positive for utilization of D-mannose, D-glucose, and L-arabinose, but negative for utilization of gluconate, adipate, malate, phenyl-acetate, D-mannitol, salicin, D-melibiose, L-fucose, D-sorbitol, propionate, caprate, valerate, citrate, L-histidine, 2-ketogluconate, 3-hydroxy-butyrate, 4-hydroxy-benzoate, L-proline, L-rhamnose, N-acetylD-glucosamine, D-ribose, inositol, D-sucrose, D-maltose, itaconate, suberate, malonate, acetate, lactate, L-alanine, 5-ketogluconate, glycogen, 3-hydroxy-benzoate, and L-serine as sole carbon and energy sources. Its cells are positive for activity of protease (gelatin hydrolysis), alkaline phosphatase, leucine arylamidase, valine arylamidase, acid phosphatase, naphtolAS-BI-phosphohydrolase and $\mathrm{N}$-acetyl- $\beta$-glucosaminidase, but negative for arginine dihydrolase, urease, $\beta$-glucosidase (esculin hydrolysis), $\beta$-galactosidase (PNPG), esterase (C4), esterase lipase (C8), lipase (C14), cystine arylamidase, trypsin, a-chymotrypsin, $\alpha$ galactosidase, $\beta$-galactosidase, $\beta$-glucuroniase, $\alpha$-glucosidase, $\beta$-glucosidase, a-mannosidase, and a-fucosidase activities. Q-8 is the only isoprenoid quinone. Its polar lipids include phosphatidylethanolamine, phosphatidylglycerol, phosphatidylcholine, and phospholipid. The major fatty acid is summed feature 8 . The $G+C$ content of the type strain was $50.70 \%$ as estimated by genome sequence.

The type strain GJ3 ${ }^{\mathrm{T}}\left(=\mathrm{KCTC} 72816^{\mathrm{T}}=\mathrm{KMM} 6822^{\mathrm{T}}\right)$ was isolated from the marine sediment collected from Jeju Island, South Korea.

The GenBank accession number for the 16S rRNA gene sequence is MK828357. The whole genomes, including two plasmid sequences, have been deposited in GenBank under the accession number CP073578, СР073579, and CP073580.

Supplementary Materials: The following supporting information can be downloaded at https: / /www.mdpi.com/article/10.3390/d14030188/s1, Figure S1: Cell morphology, Figure S2: Polar lipids profile.

Author Contributions: M.K. and S.-J.P. designed the experiments. M.K., K.-E.L., I.-T.C. and S.-J.P. performed the experiments. I.-T.C. provided support for the experiments. M.K. and S.-J.P. analyzed the data and wrote the manuscript. All authors have read and agreed to the published version of the manuscript. 
Funding: This work was supported by grants from the National Research Foundation of Korea (No. 2020R1I1A3062110) and the National Institute of Biological Resources funded by the Ministry of Environment (No. NIBR202206104).

Institutional Review Board Statement: Not applicable.

Informed Consent Statement: Not applicable.

Data Availability Statement: The GenBank/EMBL/DDBJ accession number for the 16S rRNA gene and the complete genome sequences of strain $\mathrm{GJ}^{\mathrm{T}}$ are MK828357 and CP073578-073580 (genome and two plasmids), respectively.

Conflicts of Interest: The authors declare no conflict of interest.

\section{Abbreviations}

ANI, average nucleotide identity; dDDH, digital DNA-DNA hybridization.

\section{References}

1. Vandamme, P.; Pot, B.; Gillis, M.; de Vos, P.; Kersters, K.; Swings, J. Polyphasic taxonomy, a consensus approach to bacterial systematics. Microbiol. Rev. 1996, 60, 407-438. [CrossRef] [PubMed]

2. Yarza, P.; Yilmaz, P.; Pruesse, E.; Glockner, F.O.; Ludwig, W.; Schleifer, K.H.; Whitman, W.B.; Euzeby, J.; Amann, R.; Rossello-Mora, R. Uniting the classification of cultured and uncultured bacteria and archaea using 16S rRNA gene sequences. Nat. Rev. Microbiol. 2014, 12, 635-645. [CrossRef] [PubMed]

3. Rossello-Mora, R.; Whitman, W.B. Dialogue on the nomenclature and classification of prokaryotes. Syst. Appl. Microbiol. 2019, 42, 5-14. [CrossRef] [PubMed]

4. Rossello-Mora, R.; Amann, R. Past and future species definitions for Bacteria and Archaea. Syst. Appl. Microbiol. 2015, 38, 209-216. [CrossRef]

5. Hugenholtz, P.; Chuvochina, M.; Oren, A.; Parks, D.H.; Soo, R.M. Prokaryotic taxonomy and nomenclature in the age of big sequence data. ISME J. 2021, 15, 1879-1892. [CrossRef]

6. Muller, P.A.; Epstein, S.S. In Silico Genome-Genome Hybridization Values Accurately and Precisely Predict Empirical DNA-DNA Hybridization Values for Classifying Prokaryotes. arXiv 2012, arXiv:1202.5211.

7. Kampfer, P.; Glaeser, S.P. Prokaryotic taxonomy in the sequencing era-the polyphasic approach revisited. Env. Microbiol. 2012, 14, 291-317. [CrossRef]

8. Konstantinidis, K.T.; Rossello-Mora, R.; Amann, R. Advantages outweigh concerns about using genome sequence as type material for prokaryotic taxonomy. Environ. Microbiol. 2020, 22, 819-822. [CrossRef]

9. Gupta, R.S.; Patel, S.; Saini, N.; Chen, S. Robust demarcation of 17 distinct Bacillus species clades, proposed as novel Bacillaceae genera, by phylogenomics and comparative genomic analyses: Description of Robertmurraya kyonggiensis sp. nov. and proposal for an emended genus Bacillus limiting it only to the members of the Subtilis and Cereus clades of species. Int. J. Syst. Evol. Microbiol. 2020, 70, 5753-5798.

10. Hördt, A.; Lopez, M.G.; Meier-Kolthoff, J.P.; Schleuning, M.; Weinhold, L.M.; Tindall, B.J.; Gronow, S.; Kyrpides, N.C.; Woyke, T.; Goker, M. Analysis of 1000+ type-strain genomes substantially improves taxonomic classification of Alphaproteobacteria. Front. Microbiol. 2020, 11, 468. [CrossRef]

11. Saati-Santamaría, Z.; Peral-Aranega, E.; Velázquez, E.; Rivas, R.; García-Fraile, P. Phylogenomic analyses of the genus Pseudomonas lead to the rearrangement of several species and the definition of new genera. Biology 2021, 10, 782. [CrossRef]

12. Chun, J.; Oren, A.; Ventosa, A.; Christensen, H.; Arahal, D.R.; da Costa, M.S.; Rooney, A.P.; Yi, H.; Xu, X.-W.; de Meyer, S. Proposed minimal standards for the use of genome data for the taxonomy of prokaryotes. Int. J. Syst. Evol. Microbiol. 2018, 68, 461-466. [CrossRef] [PubMed]

13. Richter, M.; Rossello-Mora, R. Shifting the genomic gold standard for the prokaryotic species definition. Proc. Natl. Acad. Sci. USA 2009, 106, 19126-19131. [CrossRef] [PubMed]

14. Auch, A.F.; von Jan, M.; Klenk, H.P.; Goker, M. Digital DNA-DNA hybridization for microbial species delineation by means of genome-to-genome sequence comparison. Stand. Genom. Sci. 2010, 2, 117-134. [CrossRef] [PubMed]

15. Rossello-Mora, R. Updating prokaryotic taxonomy. J. Bacteriol. 2005, 187, 6255-6257. [CrossRef]

16. Beijerinck, M. Le Photobacterium luminosum, Bactérie lumineuse de la mer de nord. Arch. Néerl. Sci. Exactes Nat. 1889, 23, 401-427.

17. Gomez-Gil, B.; Roque, A.; Rotllant, G.; Peinado, L.; Romalde, J.L.; Doce, A.; Cabanillas-Beltran, H.; Chimetto, L.A.; Thompson, F.L. Photobacterium swingsii sp. nov., isolated from marine organisms. Int. J. Syst. Evol. Microbiol. 2011, 61, 315-319. [CrossRef]

18. Gomez-Gil, B.; Roque, A.; Rotllant, G.; Romalde, J.L.; Doce, A.; Eggermont, M.; Defoirdt, T. Photobacterium sanguinicancri sp. nov. isolated from marine animals. Antonie Van Leeuwenhoek 2016, 109, 817-825. [CrossRef] 
19. Thompson, F.L.; Thompson, C.C.; Naser, S.; Hoste, B.; Vandemeulebroecke, K.; Munn, C.; Bourne, D.; Swings, J. Photobacterium rosenbergii sp. nov. and Enterovibrio coralii sp. nov., vibrios associated with coral bleaching. Int. J. Syst. Evol. Microbiol. 2005, 55, 913-917. [CrossRef]

20. Figge, M.J.; Cleenwerck, I.; van Uijen, A.; de Vos, P.; Huys, G.; Robertson, L. Photobacterium piscicola sp. nov., isolated from marine fish and spoiled packed cod. Syst. Appl. Microbiol. 2014, 37, 329-335. [CrossRef]

21. Deep, K.; Poddar, A.; Das, S.K. Photobacterium panuliri sp. nov., an alkalitolerant marine bacterium isolated from eggs of spiny lobster, Panulirus penicillatus from Andaman Sea. Curr. Microbiol. 2014, 69, 660-668. [CrossRef] [PubMed]

22. Ast, J.C.; Cleenwerck, I.; Engelbeen, K.; Urbanczyk, H.; Thompson, F.L.; de Vos, P.; Dunlap, P.V. Photobacterium kishitanii sp. nov., a luminous marine bacterium symbiotic with deep-sea fishes. Int. J. Syst. Evol. Microbiol. 2007, 57, 2073-2078. [CrossRef] [PubMed]

23. Chimetto, L.A.; Cleenwerck, I.; Thompson, C.C.; Brocchi, M.; Willems, A.; de Vos, P.; Thompson, F.L. Photobacterium jeanii sp. nov., isolated from corals and zoanthids. Int. J. Syst. Evol. Microbiol. 2010, 60, 2843-2848. [CrossRef] [PubMed]

24. Machado, H.; Giubergia, S.; Mateiu, R.V.; Gram, L. Photobacterium galatheae sp. nov., a bioactive bacterium isolated from a mussel in the Solomon Sea. Int. J. Syst. Evol. Microbiol. 2015, 65, 4503-4507. [CrossRef] [PubMed]

25. Seo, H.J.; Bae, S.S.; Yang, S.H.; Lee, J.H.; Kim, S.J. Photobacterium aplysiae sp. nov., a lipolytic marine bacterium isolated from eggs of the sea hare Aplysia kurodai. Int. J. Syst. Evol. Microbiol. 2005, 55, 2293-2296. [CrossRef]

26. Urbanczyk, H.; Ast, J.C.; Dunlap, P.V. Phylogeny, genomics, and symbiosis of Photobacterium. FEMS Microbiol. Rev. 2011, 35, 324-342. [CrossRef]

27. Kim, M.; Cha, I.T.; Lee, K.E.; Lee, B.H.; Park, S.J. Kineobactrum salinum sp. nov., isolated from marine sediment. Int. J. Syst. Evol. Microbiol. 2021, 71. [CrossRef]

28. Li, M.; Kong, D.; Wang, Y.; Ma, Q.; Han, X.; Zhou, Y.; Jiang, X.; Zhang, Y.; Ruan, Z.; Zhang, Q. Photobacterium salinisoli sp. nov., isolated from a sulfonylurea herbicide-degrading consortium enriched with saline soil. Int. J. Syst. Evol. Microbiol. 2019, 69, 3910-3916. [CrossRef]

29. Weisburg, W.G.; Barns, S.M.; Pelletier, D.A.; Lane, D.J. 16S ribosomal DNA amplification for phylogenetic study. J. Bacteriol. 1991, 173, 697-703. [CrossRef]

30. Koh, H.W.; Hong, H.; Min, U.G.; Kang, M.S.; Kim, S.G.; Na, J.G.; Rhee, S.K.; Park, S.J. Rhodanobacter aciditrophus sp. nov., an acidophilic bacterium isolated from mine wastewater. Int. J. Syst. Evol. Microbiol. 2015, 65, 4574-4579. [CrossRef]

31. Thompson, J.D.; Gibson, T.J.; Plewniak, F.; Jeanmougin, F.; Higgins, D.G. The CLUSTAL_X windows interface: Flexible strategies for multiple sequence alignment aided by quality analysis tools. Nucleic Acids Res. 1997, 25, 4876-4882. [CrossRef] [PubMed]

32. Kimura, M. The neutral theory of molecular evolution and the world view of the neutralists. Genome 1989, 31, 24-31. [CrossRef] [PubMed]

33. Saitou, N.; Nei, M. The neighbor-joining method: A new method for reconstructing phylogenetic trees. Mol. Biol. Evol. 1987, 4, 406-425. [PubMed]

34. Fitch, W.M. Toward defining the course of evolution: Minimum change for a specific tree topology. Syst. Biol. 1971, 20, 406-416. [CrossRef]

35. Felsenstein, J. Evolutionary trees from DNA sequences: A maximum likelihood approach. J. Mol. Evol. 1981, 17, 368-376. [CrossRef]

36. Kumar, S.; Stecher, G.; Li, M.; Knyaz, C.; Tamura, K. MEGA X: Molecular evolutionary genetics analysis across computing platforms. Mol. Biol. Evol. 2018, 35, 1547-1549. [CrossRef] [PubMed]

37. Webley, D.M. A simple method for producing microcultures in hanging drops with special reference to organisms utilizing oils. J. Gen. Microbiol. 1953, 8, 66-71. [CrossRef]

38. Smibert, R.; Kreig, N. Phenotypic characterization. In Methods for General and Molecular Bacteriology; Gerhardt, P.M.R., Wood, W.A., Krieg, N.R., Eds.; American Society for Microbiology: Washington, DC, USA, 1994; pp. 607-654.

39. Hu, H.Y.; Fujie, K.; Urano, K. Development of a novel solid phase extraction method for the analysis of bacterial quinones in activated sludge with a higher reliability. J. Biosci. Bioeng. 1999, 87, 378-382. [CrossRef]

40. Minnikin, D.; O'donnell, A.; Goodfellow, M.; Alderson, G.; Athalye, M.; Schaal, A.; Parlett, J. An integrated procedure for the extraction of bacterial isoprenoid quinones and polar lipids. J. Microbiol. Methods 1984, 2, 233-241. [CrossRef]

41. Minnikin, D.; Patel, P.; Alshamaony, L.; Goodfellow, M. Polar lipid composition in the classification of Nocardia and related bacteria. Int. J. Syst. Evol. Microbiol. 1977, 27, 104-117. [CrossRef]

42. Chin, C.S.; Alexander, D.H.; Marks, P.; Klammer, A.A.; Drake, J.; Heiner, C.; Clum, A.; Copeland, A.; Huddleston, J.; Eichler, E.E.; et al. Nonhybrid, finished microbial genome assemblies from long-read SMRT sequencing data. Nat. Methods 2013, 10, 563-569. [CrossRef] [PubMed]

43. Konstantinidis, K.T.; Tiedje, J.M. Prokaryotic taxonomy and phylogeny in the genomic era: Advancements and challenges ahead. Curr. Opin. Microbiol. 2007, 10, 504-509. [CrossRef] [PubMed]

44. Konstantinidis, K.T.; Tiedje, J.M. Towards a genome-based taxonomy for prokaryotes. J. Bacteriol. 2005, 187, 6258-6264. [CrossRef]

45. Meier-Kolthoff, J.P.; Auch, A.F.; Klenk, H.P.; Goker, M. Genome sequence-based species delimitation with confidence intervals and improved distance functions. BMC Bioinform. 2013, 14, 60. [CrossRef] [PubMed]

46. Tatusova, T.; DiCuccio, M.; Badretdin, A.; Chetvernin, V.; Nawrocki, E.P.; Zaslavsky, L.; Lomsadze, A.; Pruitt, K.D.; Borodovsky, M.; Ostell, J. NCBI prokaryotic genome annotation pipeline. Nucleic Acids Res. 2016, 44, 6614-6624. [CrossRef] [PubMed] 
47. Meier-Kolthoff, J.P.; Goker, M. TYGS is an automated high-throughput platform for state-of-the-art genome-based taxonomy. Nat. Commun. 2019, 10, 2182. [CrossRef] [PubMed]

48. Meier-Kolthoff, J.P.; Carbasse, J.S.; Peinado-Olarte, R.L.; Goker, M. TYGS and LPSN: A database tandem for fast and reliable genome-based classification and nomenclature of prokaryotes. Nucleic Acids Res. 2021, 50, D801-D807. [CrossRef]

49. Lefort, V.; Desper, R.; Gascuel, O. FastME 2.0: A comprehensive, accurate, and fast distance-based phylogeny inference program. Mol. Biol. Evol. 2015, 32, 2798-2800. [CrossRef]

50. Farris, J.S. Estimating phylogenetic trees from distance matrices. Am. Nat. 1972, 106, 645-668. [CrossRef]

51. Kreft, L.; Botzki, A.; Coppens, F.; Vandepoele, K.; van Bel, M. PhyD3: A phylogenetic tree viewer with extended phyloXML support for functional genomics data visualization. Bioinformatics 2017, 33, 2946-2947. [CrossRef]

52. Arndt, D.; Grant, J.R.; Marcu, A.; Sajed, T.; Pon, A.; Liang, Y.; Wishart, D.S. PHASTER: A better, faster version of the PHAST phage search tool. Nucleic Acids Res. 2016, 44, W16-W21. [CrossRef] [PubMed]

53. Blin, K.; Shaw, S.; Kloosterman, A.M.; Charlop-Powers, Z.; van Wezel, G.P.; Medema, M.H.; Weber, T. antiSMASH 6.0: Improving cluster detection and comparison capabilities. Nucleic Acids Res. 2021, 49, W29-W35. [CrossRef] [PubMed]

54. Grissa, I.; Vergnaud, G.; Pourcel, C. CRISPRFinder: A web tool to identify clustered regularly interspaced short palindromic repeats. Nucleic Acids Res. 2007, 35, W52-W57. [CrossRef] [PubMed]

55. Unden, G.; Becker, S.; Bongaerts, J.; Schirawski, J.; Six, S. Oxygen regulated gene expression in facultatively anaerobic bacteria Antonie Van Leeuwenhoek 1994, 66, 3-22. [CrossRef]

56. Maklashina, E.; Berthold, D.A.; Cecchini, G. Anaerobic expression of Escherichia coli succinate dehydrogenase: Functional replacement of fumarate reductase in the respiratory chain during anaerobic growth. J. Bacteriol. 1998, 180, 5989-5996. [CrossRef]

57. Empadinhas, N.; da Costa, M.S. Osmoadaptation mechanisms in prokaryotes: Distribution of compatible solutes. Int. Microbiol. 2008, 11, 151-161.

58. Machado, H.; Gram, L. Comparative genomics reveals high genomic diversity in the genus Photobacterium. Front. Microbiol. 2017, 8, 1204. [CrossRef]

59. Rimando, A.M.; Baerson, S.R. Polyketides: Biosynthesis, Biological Activity, and Genetic Engineering; American Chemical Society: Washington, DC, USA, 2007.

60. Takano, E. $\gamma$-butyrolactones: Streptomyces signalling molecules regulating antibiotic production and differentiation. Curr. Opin. Microbiol. 2006, 9, 287-294. [CrossRef]

61. Sharpe, G.C.; Gifford, S.M.; Septer, A.N. A Model Roseobacter, Ruegeria pomeroyi DSS-3, employs a diffusible killing mechanism to eliminate competitors. mSystems 2020, 5, e00443-20. [CrossRef]

62. Osorio, C.R.; Juiz-Rio, S.; Lemos, M.L. A siderophore biosynthesis gene cluster from the fish pathogen Photobacterium damselae subsp. piscicida is structurally and functionally related to the Yersinia high-pathogenicity island. Int. J. Syst. Evol. Microbiol. 2006, 152, 3327-3341. [CrossRef]

63. Russo, T.A.; Olson, R.; Macdonald, U.; Metzger, D.; Maltese, L.M.; Drake, E.J.; Gulick, A.M. Aerobactin mediates virulence and accounts for increased siderophore production under iron-limiting conditions by hypervirulent (hypermucoviscous) Klebsiella pneumoniae. Infect. Immun. 2014, 82, 2356-2367. [CrossRef] [PubMed]

64. Thode, S.K.; Rojek, E.; Kozlowski, M.; Ahmad, R.; Haugen, P. Distribution of siderophore gene systems on a Vibrionaceae phylogeny: Database searches, phylogenetic analyses and evolutionary perspectives. PLoS ONE 2018, 13, e0191860. [CrossRef] [PubMed]

65. Mathew, D.C.; Lo, S.C.; Mathew, G.M.; Chang, K.H.; Huang, C.C. Genomic sequence analysis of a plant-associated Photobacterium halotolerans MELD1: From marine to terrestrial environment? Stand Genomic. Sci. 2016, 11, 56. [CrossRef] [PubMed]

66. Thompson, J.R.; Pacocha, S.; Pharino, C.; Klepac-Ceraj, V.; Hunt, D.E.; Benoit, J.; Sarma-Rupavtarm, R.; Distel, D.L.; Polz, M.F. Genotypic diversity within a natural coastal bacterioplankton population. Science 2005, 307, 1311-1313. [CrossRef] [PubMed]

67. Boto, L. Horizontal gene transfer in evolution: Facts and challenges. Proc. Biol. Sci. 2010, 277, 819-827. [CrossRef] [PubMed] 